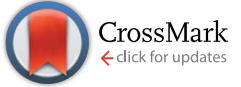

Cite this: RSC Adv., 2017, 7, 11403

Received 29th December 2016 Accepted 31st January 2017

DOI: 10.1039/c6ra28796d

rsc.li/rsc-advances

\section{Synthesis of magnetic carbonaceous acids derived from hydrolysates of Jatropha hulls for catalytic biodiesel production $\uparrow$}

\begin{abstract}
Fan Zhang, $t^{\text {ad }}$ Xiaofei Tian, $t^{\mathrm{b}}$ Mazloom Shah ${ }^{\mathrm{ac}}$ and Wenjing Yang ${ }^{\mathrm{a}}$
A series of magnetic carbonaceous acids $\left(\mathrm{JHC}-T_{1}-T_{2}-\mathrm{SO}_{3} \mathrm{HaFe} / \mathrm{Fe}_{3} \mathrm{O}_{4}\right.$ ) were synthesized by the assembly of nano- $\mathrm{Fe}_{3} \mathrm{O}_{4}$ magnetic cores (particle size $<20 \mathrm{~nm}$ ) and carbon coatings derived from hydrolysates of Jatropha hulls. A magnetic $\mathrm{JHC}-12-600-\mathrm{SO}_{3} \mathrm{HaFe} / \mathrm{Fe}_{3} \mathrm{O}_{4}$ catalyst with a total acid content of $2.69 \mathrm{mmol} \mathrm{g} \mathrm{m}^{-1}$ and a magnetic saturation of $40.3 \mathrm{~A} \mathrm{~m}^{2} \mathrm{~kg}^{-1}$ was successfully prepared via a sequence of hydrothermal precipitation, pyrolytic carbonization, and finally sulfonation with $\mathrm{H}_{2} \mathrm{SO}_{4}$. The catalyst was directly used for the production of biodiesel from Jatropha crude oil with an acid value (AV) of $17.2 \mathrm{mg} \mathrm{KOH}$ per g, and the optimized conditions $\left(180^{\circ} \mathrm{C}\right.$ for $7.5 \mathrm{~h}$ with a molar ratio of methanol/oil of $18 / 1$ and a catalyst loading of 7.5 wt\%) were determined by single-factor tests. An average biodiesel yield of $95.9 \%$ was achieved with a recovery rate of $94.3 \%$ after 5 reaction cycles in a $5 \mathrm{~L}$ batch reactor for testing the feasibility of the catalyst for large-scale use. This study demonstrates an alternative green approach to fully utilizing waste biomass from energy plants in the catalytic synthesis of Jatropha biodiesel with high efficiency.
\end{abstract}

\section{Introduction}

Limitations in fossil oil reserves and global warming have become serious problems because of the growing global demand for energy and the accumulation of atmospheric $\mathrm{CO}_{2}$ by the combustion of fossil fuels. ${ }^{\mathbf{1 , 2}}$ Biodiesel is considered to be an alternative liquid fuel owing to the advantage that it is clean and renewable. ${ }^{3,4}$ Because heterogeneous catalysts are easier to recover from the reaction system than liquid acid or alkaline catalysts, ${ }^{5}$ solid catalysts have been widely employed in the production of biodiesel. Solid basic catalysts including $\mathrm{K} / \mathrm{SiO}_{2},{ }^{6}$ $\mathrm{CaO}$ from eggshells ${ }^{7}$ and calcium-modified porous aluminosilicates ${ }^{8}$ have commonly been used in the production of biodiesel owing to their high performance in transesterification reactions of oils with a low acid value (AV). Natural Jatropha oil is a promising raw material for the production of biodiesel with suitable properties. ${ }^{9-11}$ However, it always has a high $\mathrm{AV}$, which

\footnotetext{
${ }^{a}$ Biomass Group, Key Laboratory of Tropical Plant Resources and Sustainable Use, Xishuangbanna Tropical Botanical Garden, Chinese Academy of Sciences, 88 Xuefulu, Kunming, Yunnan, 650223, China. E-mail: zhangfan@xtbg.ac.cn; Web: http://www.tprsu.xtbg.ac.cn/; Fax: +86-871-65160916; Tel: +86-871-65180637

${ }^{b}$ School of Bioscience and Bioengineering, South China University of Technology, University Mega Centre, Guangzhou, Guangdong, 510006, China. E-mail: xtien@ scut.edu.cn

${ }^{\circ}$ Department of Chemistry, Women University of Azad Jammu and Kashmir, Bagh, 12500, Pakistan. E-mail: shahmazloom@gmail.com

${ }^{d}$ University of Chinese Academy of Sciences, 19A Yuquan Road, Beijing, 100049, China $\dagger$ Electronic supplementary information (ESI) available. See DOI: 10.1039/c6ra28796d

\$ Co-first authors.
}

is caused by long-term storage. ${ }^{12,13}$ To avoid the direct use of basic catalysts, which would cause severe saponification of the reaction system during the transesterification of Jatropha oil, deoxygenation of fatty acids ${ }^{\mathbf{1 4}}$ and transesterification with enzyme $^{15}$ or solid acid catalysts ${ }^{16-18}$ are effective methods that have been widely employed in the production of biodiesel. However, deficiencies in these methods, such as the high cost of lipases, harsh deoxygenation conditions and incomplete separation of the catalyst particles from the products, remained and posed challenges to their further utilization in the large-scale production of biodiesel. ${ }^{14-18}$

When catalyzing hydrolysis, esterification and dehydration reactions, solid acid catalysts, in particular sulfonated solid acid catalysts, exhibited excellent performance in the conversion of various alternative carbon resources, such as lignocellulosic biomass, ${ }^{19}$ sugars, ${ }^{20}$ and non-edible oils, ${ }^{21,22}$ for the purposes of producing fuels and high-value-added chemicals. For example, sulfated mesoporous niobium oxide (MNO-S) was developed as a catalyst for the production of 5-hydroxymethylfurfural (5HMF). It catalyzed the hydrolysis and dehydration reactions of various disaccharide substrates and exhibited promising feasibility owing to a relatively high yield of 5-HMF and excellent recyclability. ${ }^{20}$

As sulfonated active carbon has been successfully employed in the catalytic production of biodiesel from crude Jatropha oil with a high $\mathrm{AV}$ of $12.7 \mathrm{mg} \mathrm{KOH}$ per $\mathrm{g},{ }^{22,23}$ the efficient recycling of solid carbons is of key importance for the purpose of reusing catalysts. Centrifugation and filtration methods have been commonly used, but both of them operated with low time or energy efficiency. ${ }^{22}$ The introduction of a magnetic field for the 
isolation of catalysts from the reaction system was a practical approach without intensive consumption of time or energy. Magnetic carbonaceous acids provided a convenient way of using a magnet for the isolation of catalysts. Novel carbonbased materials, including sulfonated magnetic lignin-derived amorphous carbon solid acids $\left(\mathrm{MLC}^{\left.-\mathrm{SO}_{3} \mathrm{H}\right)}{ }^{24}\right.$ magnetic carbon nanotube arrays (sulfonated MCNAs) ${ }^{25}$ and magnetic carbonaceous acids, ${ }^{\mathbf{1 9 , 2 6 , 2 7}}$ were synthesized and successfully used in catalyzing the dehydration of fructose and the hydrolysis of polysaccharides and cellulose, respectively. However, these reported magnetic carbonaceous acids were not adequate for employment in the production of biodiesel with high efficiency owing to their relatively low acidity or magnetism (Table 1).

In our previous work, ${ }^{28}$ an alternative magnetic AC-600$\mathrm{SO}_{3} \mathrm{H} @ \mathrm{Fe} / \mathrm{C}$ catalyst with high acidity and magnetic saturation was synthesized using glucose as the source of the carbon coating. With remarkably high efficiency in the transesterification of Jatropha oil and a high catalyst recovery rate, it was successfully employed for the production of Jatropha biodiesel. As the synthesis of the catalyst required edible sugar and complicated operations (Table 1), we therefore developed

Table 1 Preparation, acid content and magnetism of selected magnetic carbonaceous acids

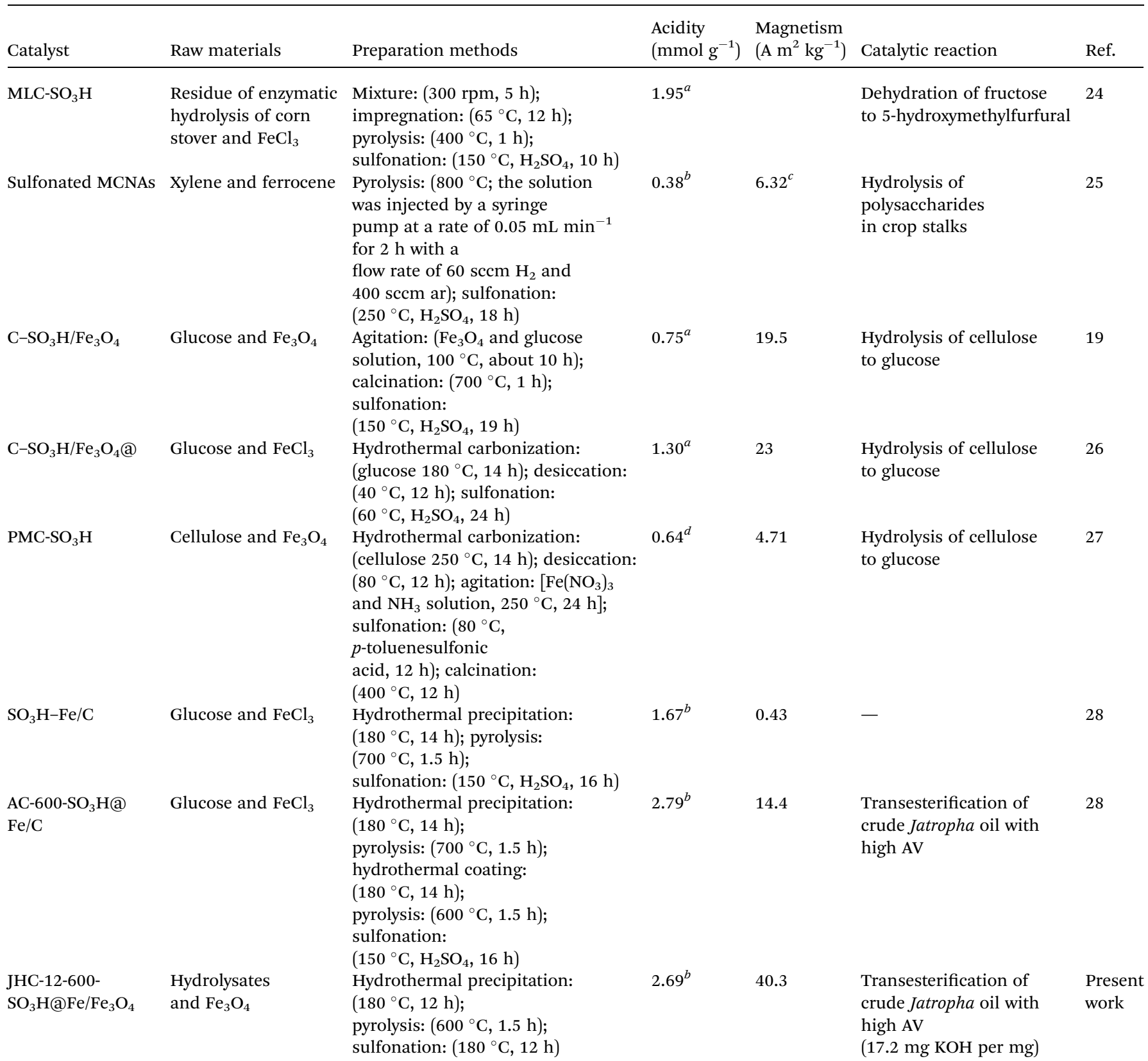

${ }^{a}$ By acid-base titration. ${ }^{b}$ By $\mathrm{NH}_{3}$-TPD analysis. ${ }^{c}$ Before sulfonation. ${ }^{d}$ Calculated on the assumption that all the sulfur atoms were associated with sulfonic acid groups. 
a method for preparing a series of magnetic carbonaceous acids via hydrothermal precipitation, pyrolytic carbonization and sulfonation using nano- $\mathrm{Fe}_{3} \mathrm{O}_{4}$ particles and hydrolysates of Jatropha hulls as alternative raw materials. The prepared magnetic carbonaceous acid that had the highest acidity and a relatively high magnetic saturation was selected and employed for the production of Jatropha biodiesel under conditions optimized by single-factor experiments.

\section{Experiments}

\subsection{Materials}

Nano- $\mathrm{Fe}_{3} \mathrm{O}_{4}$ particles $(\geq 99.5 \%$, particle size $<20 \mathrm{~nm})$ were purchased from Aladdin Industrial Corporation (Shanghai, China). Analytical reagents, namely, concentrated $\mathrm{H}_{2} \mathrm{SO}_{4}$ $(\geq 98.0 \%), \quad \mathrm{Ca}(\mathrm{OH})_{2} \quad(\geq 95.0 \%)$, methanol $(\geq 99.5 \%), \quad \mathrm{KOH}$ $(\geq 85.0 \%)$, dehydrated ethanol ( $\geq 99.5 \%)$ and phenolphthalein were purchased from Xilong Chemical Factory Co., Ltd. (Shantou, Guangzhou, China). Standard materials of heptadecanoic acid methyl ester $\left(\mathrm{C}_{17: 0}\right)$ and other aliphatic acid methyl esters [palmitate $\left(\mathrm{C}_{16: 0}\right)$, palmitoleate $\left(\mathrm{C}_{16: 1}\right)$, stearate $\left(\mathrm{C}_{18: 0}\right)$, oleate $\left(\mathrm{C}_{18: 1}\right)$, linoleate $\left(\mathrm{C}_{18: 2}\right)$ and linolenate $\left.\left(\mathrm{C}_{18: 3}\right)\right](\geq 99.0 \%)$ were purchased from Sigma-Aldrich (Shanghai, China).

Jatropha hulls were purchased from Yunnan Shenyu New Energy Co., Ltd. (Chuxiong, Yunnan, China). Before use, they were dried at $75{ }^{\circ} \mathrm{C}$ for $48 \mathrm{~h}$ and ground to pass through a sieve (80 mesh) using a pulverizer (9FC15, Xudong Machinery Manufacturing Co., Ltd, Leshan, Sichuan, China). Elemental analysis of the Jatropha hulls was performed using an elemental analyzer (Vario EL III CHNS, Elementar Analysensysteme GmbH, Hanau, Germany). The contents of C, $\mathrm{H}$ and $\mathrm{O}$ were $48.6 \%, 7.23 \%$ and $41.1 \% \mathrm{wt}$, respectively (Table 2). For acid hydrolysis, $15 \mathrm{~g}$ Jatropha hulls were loaded in a $300 \mathrm{~mL} \mathrm{ZrO}_{2}$ reactor (FCFD03-30, Jianbang Chemical Mechanical Co. Ltd, Yantai, Shandong) containing $200 \mathrm{~mL}$ of $3 \mathrm{wt} \%$ concentrated $\mathrm{H}_{2} \mathrm{SO}_{4}$ solution. The suspension was thoroughly mixed by stirring at $300 \mathrm{rpm}$ and heated to $150{ }^{\circ} \mathrm{C}$. After $1.5 \mathrm{~h}$, the reactor was cooled immediately. The residue of Jatropha hulls was removed by passing them through a filter (Merck Millipore, pore size $1.2 \mu \mathrm{m}$ ), and the hydrolysates were neutralized by adding $\mathrm{Ca}(\mathrm{OH})_{2}$ until the $\mathrm{pH}$ was 6.5-7.0. After filtration, the hydrolysates were further concentrated at $65{ }^{\circ} \mathrm{C}$ in a rotary evaporator (RE-52AA, Yancheng Instrument Co., Ltd, Shanghai, China). A concentration of soluble carbon of $61 \mathrm{~g} \mathrm{~L}^{-1}$ in the hydrolysates was finally achieved. Crude Jatropha oil (stored for six years) was obtained from Xishuangbanna Tropical Botanical Garden, Chinese Academy of Sciences.

\subsection{Catalyst preparation}

Firstly, $20 \mathrm{~g}$ nano- $\mathrm{Fe}_{3} \mathrm{O}_{4}$ particles (magnetic cores) were loaded into a $500 \mathrm{~mL} \mathrm{ZrO}_{2}$ reactor (FCFD05-30, Jianbang Chemical Mechanical Co., Ltd, Yantai, Shandong, China) containing 0.4 L concentrated hydrolysates of Jatropha hulls. The mixture was maintained at $180^{\circ} \mathrm{C}$ for different hydrothermal precipitation times $(4,8,12,16$ and $20 \mathrm{~h})$ while being stirred at $500 \mathrm{rpm}$. After the hydrothermal reaction, the solid product was recovered and washed with deionized water several times until a neutral solution was obtained. The neutralized solid product was saturated with dehydrated ethanol and freeze-dried at $-47^{\circ} \mathrm{C}$ in a freeze-dryer (PDU-1200, EYELA, Tokyo Rikakikai Co., Ltd, Japan) for $24 \mathrm{~h}$. Carbonization of the magnetic carbonaceous precursor was performed in a tubular furnace (SGL-1100, Daheng Optics and Fine Mechanics Co., Ltd, Shanghai, China) with a nitrogen flow of $200 \mathrm{~mL} \mathrm{~min}^{-1}$. The temperatures in the oven reached $200,400,500,600,700$ and $800{ }^{\circ} \mathrm{C}$ with a heating rate of $1.9-8.6^{\circ} \mathrm{C} \mathrm{min}{ }^{-1}$ for $1.5 \mathrm{~h}$. The products were designated as JHC- $T_{1}-T_{2} @ \mathrm{Fe} / \mathrm{Fe}_{3} \mathrm{O}_{4}\left(T_{1}\right.$ is the hydrothermal precipitation time, $T_{2}$ is the temperature of pyrolytic carbonization), respectively.

A $10 \mathrm{~g}$ sample of JHC- $T_{1}-T_{2} @ \mathrm{Fe} / \mathrm{Fe}_{3} \mathrm{O}_{4}$ was added to a $500 \mathrm{~mL}$ flask containing $200 \mathrm{~mL}$ concentrated $\mathrm{H}_{2} \mathrm{SO}_{4}$. The mixture was maintained at $180{ }^{\circ} \mathrm{C}$ for $12 \mathrm{~h}$ under a nitrogen flow $(100 \mathrm{~mL}$ $\mathrm{min}^{-1}$ ). The sulfonated JHC- $T_{1}-T_{2} @ \mathrm{Fe} / \mathrm{Fe}_{3} \mathrm{O}_{4} \quad$ (JHC- $T_{1}-T_{2^{-}}$ $\left.\mathrm{SO}_{3} \mathrm{H} @ \mathrm{Fe} / \mathrm{Fe}_{3} \mathrm{O}_{4}\right)$ that was obtained was washed with hot distilled water $\left(70-80^{\circ} \mathrm{C}\right)$ until the $\mathrm{pH}$ was $6.5-7$. To remove the residual $\mathrm{SO}_{4}{ }^{2-}$, the neutralized JHC- $T_{1}-T_{2}-\mathrm{SO}_{3} \mathrm{H} @ \mathrm{Fe} / \mathrm{Fe}_{3} \mathrm{O}_{4}$ was hydrothermally treated with water at $180{ }^{\circ} \mathrm{C}$ for $3 \mathrm{~h}$ in the reactor. The treated JHC- $T_{1}-T_{2}-\mathrm{SO}_{3} \mathrm{H} @ \mathrm{Fe} / \mathrm{Fe}_{3} \mathrm{O}_{4}$ was washed and freeze-dried. Before being used for the production of biodiesel, the prepared catalyst was ground and sieved through a 200 mesh screen.

\subsection{Instrumentation}

The total acid content (TAC) was measured by the temperatureprogrammed desorption (TPD) method using a chemisorption analyzer (Quantachrome Instruments, Boynton Beach, FL,

Table 2 Elemental compositions (C, H, N, S and Fe) of Jatropha hulls, the magnetic JHC-12-600@Fe/Fe $\mathrm{O}_{4}$ precursor and the magnetic JHC$12-600-\mathrm{SO}_{3} \mathrm{HaFe} / \mathrm{Fe}_{3} \mathrm{O}_{4}$ catalyst

\begin{tabular}{lllll}
\hline $\mathrm{Wt} \%$ & Jatropha hulls & $\mathrm{JHC}-12-600 @ \mathrm{Fe} / \mathrm{Fe}_{3} \mathrm{O}_{4}$ & $\mathrm{JHC}-12-600-\mathrm{SO}_{3} \mathrm{H} @ \mathrm{Fe} / \mathrm{Fe}_{3} \mathrm{O}_{4}$ & $\mathrm{JHC}-12-600-\mathrm{SO}_{3} \mathrm{H} @ \mathrm{Fe} / \mathrm{Fe}_{3} \mathrm{O}_{4}{ }^{d}$ \\
\hline $\mathrm{C}^{a}$ & 48.6 & 35.1 & 40.7 & 41.5 \\
$\mathrm{H}^{a}$ & 7.23 & 3.88 & 2.27 & 2.44 \\
$\mathrm{O}^{b}$ & 41.1 & 16.2 & 32.5 & - \\
$\mathrm{N}^{a}$ & 2.67 & 1.67 & 1.11 & 0.82 \\
$\mathrm{~S}^{a}$ & 0.173 & 0.250 & 3.62 & 2.37 \\
$\mathrm{Fe}^{c}$ & 0.227 & 42.9 & 19.8 & -
\end{tabular}

${ }^{a}$ Analyzed by Vario EL III CHNS elemental analyzer. ${ }^{b} \mathrm{O}$ (wt $\left.\%\right)$ was calculated as $100 \mathrm{wt} \%-\left(\mathrm{C}, \mathrm{H}, \mathrm{N}, \mathrm{S}\right.$, and Fe) wt $\%{ }^{c}$ Analyzed by ICP-OES. ${ }^{d}$ JHC$12-600-\mathrm{SO}_{3} \mathrm{H} @ \mathrm{Fe} / \mathrm{Fe}_{3} \mathrm{O}_{4}$ catalyst after 5 cycles of use. 
USA). About $50-100 \mathrm{mg}$ of the catalyst was used for TPD analysis. The program used for the reacting gas and sample temperature was as follows: standard gas $\left(10 \% \mathrm{NH}_{3}\right.$ with $90 \%$ He, v/v, Yunnan Messer Co., Ltd, Kunming, China) was supplied for $60 \mathrm{~min}$ at $50{ }^{\circ} \mathrm{C}$ at a flow rate of $85 \mathrm{~mL} \mathrm{~min}{ }^{-1}$ and then converted to He gas (99.999\%, Yunnan Messer Co., Ltd, Kunming, China), and the temperature was gradually increased to $400{ }^{\circ} \mathrm{C}$ at a heating rate of $5{ }^{\circ} \mathrm{C} \mathrm{min}{ }^{-1}$ over $60-90 \mathrm{~min}$. The total acid content was calculated using an external standard, which was calibrated against $0.5,1,1.5$, and $2 \mathrm{~mL}$ of a standard gas (10\% $\mathrm{NH}_{3}$ with $90 \%$ helium). Saturation magnetization (Ms) was measured using a vibrating sample magnetometer (VSM; Lake Shore 7407, Lake Shore Cryotronics, Inc., Westerville, $\mathrm{OH}$, USA). Crystal structures were determined using an X-ray diffractometer (XRD; Rigaku Rotaflex RAD-C, Tokyo, Japan) equipped with a $\mathrm{Cu} \mathrm{K} \alpha$ radiation source. All samples were equally loaded. The composition of metallic oxides in the catalyst was determined according to a pairwise comparison of diffraction patterns with standard records (Joint Committee on Powder Diffraction Standards, JCPDS: 89-2355, 06-0696, 72-1110 and 39-1346). ${ }^{29}$ The surface morphologies and microstructures of the catalysts and precursors were characterized using a scanning electron microscope (SEM; Zeiss EVO LS10, Cambridge, UK). The samples were loaded on copper mounts with double-sided electrically conductive adhesive carbon tape without gold coatings. Observations with the SEM were conducted using an accelerating voltage of $10.00 \mathrm{kV}$ at a working distance of $15.5 \mathrm{~mm}$. Transmission electron microscopy (TEM) images were recorded using a JEOL JEM-2010 microscope at an accelerating voltage of $200 \mathrm{kV}$. A suspension of the catalyst or precursor, which had been well dispersed in ethanol by ultrasonication, was dropped onto the copper grid and air-dried before being subjected to observation. Surface areas were selected and scanned by energy-dispersive X-ray spectrometry (EDX; Quanta 200, Hillsboro, OR, USA) for the determination of semi-quantitative elemental compositions ( $\mathrm{C}, \mathrm{O}, \mathrm{Fe}$ and $\mathrm{S}$ ). Functional groups were identified by Fourier transform infrared spectroscopy (FT-IR; Nicolet iS10, Thermo Fisher Scientific Co., Ltd, Waltham, MA, USA) within the spectral range of 400-4000 $\mathrm{cm}^{-1}$. A $0.05 \mathrm{~g}$ freeze-dried sample was blended with $0.5 \mathrm{~g}$ spectroscopic grade $\mathrm{KBr}$ in an agate mortar and then pressed into a disc. The $\mathrm{KBr}$ disc was scanned with a resolution in the range of $0.4-4 \mathrm{~cm}^{-1}$. The thermal stability of samples was determined using a thermogravimetric analyzer (TGA; TA Q500 HiRes, TA Instruments, New Castle, DE, USA). With $5 \mathrm{mg}$ freezedried catalyst loaded in the TGA crucible, data were collected at temperatures rising from 40 to $800{ }^{\circ} \mathrm{C}$ at $5{ }^{\circ} \mathrm{C} \mathrm{min}^{-1}$ under a helium gas atmosphere flowing at $50 \mathrm{~mL} \mathrm{~min}{ }^{-1}$. The Brunauer-Emmett-Teller (BET) surface area and pore volume were measured by the nitrogen adsorption-desorption method using a TriStar II 3020 (Micromeritics Instrument Co., Ltd, Norcross, GA, USA). The samples were degassed at $120{ }^{\circ} \mathrm{C}$ for $3 \mathrm{~h}$ before analysis. The elemental composition was determined using an elemental analyzer (Vario EL III CHNS, Elementar Analysensysteme GmbH, Hanau, Germany). The catalysts were dissolved in an oxidizing agent containing $10 \% \mathrm{HCl}$ and $3.5 \%$ $\mathrm{HNO}_{3}(\mathrm{w} / \mathrm{w})$. The Fe content was determined by an inductively coupled plasma-optical emission spectrometer (ICP-OES; Optima 5300 DV, PerkinElmer Inc., Waltham, MA, USA).

\subsection{Biodiesel production and catalyst recovery}

The catalytic esterification and transesterification of crude Jatropha oil were performed in a $50 \mathrm{~mL}$ batch reactor (YZPR-50, Yanzheng Experimental Instrument Co., Ltd, Shanghai, China) equipped with a quartz cup (Fig. 1). With a dead volume of $9.6 \mathrm{~mL}$, the sealed reactor containing $18.6 \mathrm{~g}(0.02 \mathrm{~mol})$ crude Jatropha oil, methanol (in a molar ratio to the oil of $6: 1-30: 1$ ) and the catalyst (2.5-12.5 wt\% of the oil) was pressurized with nitrogen (2.0 MPa, 99.99\%, Yunnan Messer Co., Ltd, Kunming, China) to avoid the evaporation of methanol at high temperatures. The reaction was conducted at $160-200{ }^{\circ} \mathrm{C}$ with a heating time of $25-35 \mathrm{~min}$ allowed before reaching the reaction temperature. After the reaction, the catalyst was isolated from the liquid using an NdFeB magnet (Fig. 1c) and subjected to direct reuse without any treatment.

The large-scale production of Jatropha biodiesel in a $5 \mathrm{~L}$ batch reactor (FCFD05-30, Jianbang Chemical Mechanical Co., Ltd, Yantai, Shandong, China) with a dead volume of $36.7 \mathrm{~mL}$ (Fig. 2) was performed over the selected catalyst under conditions optimized via small-scale experiments. Before the reaction, an appropriate amount of the magnetic catalyst was first loaded on an NdFeB magnet fixed on the mixer shaft (Fig. 2b). Crude Jatropha oil (1.86 kg, $2 \mathrm{~mol}$ ) and methanol were pumped into the reactor, which was sealed and then pressurized with nitrogen (99.999\% purity, 2.0 MPa). High-speed stirring at $500 \mathrm{rpm}$ was applied to homogenize the mixture with the catalyst. Then the

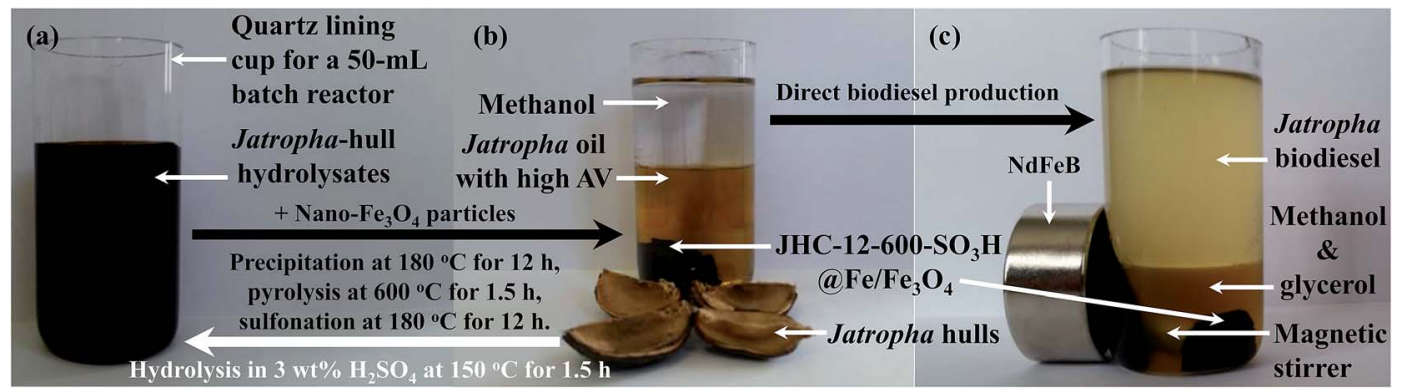

Fig. 1 Images of (a) hydrolysates of Jatropha hulls, (b) a mixture of magnetic $\mathrm{JHC}-12-600-\mathrm{SO}_{3} \mathrm{H}\left(\mathrm{Fe} / \mathrm{Fe}_{3} \mathrm{O}_{4}\right.$ with Jatropha oil and methanol in a $50 \mathrm{~mL}$ batch reactor, and (c) the catalyst recovered by an $\mathrm{NdFeB}$ magnet from the synthesized Jatropha biodiesel. 


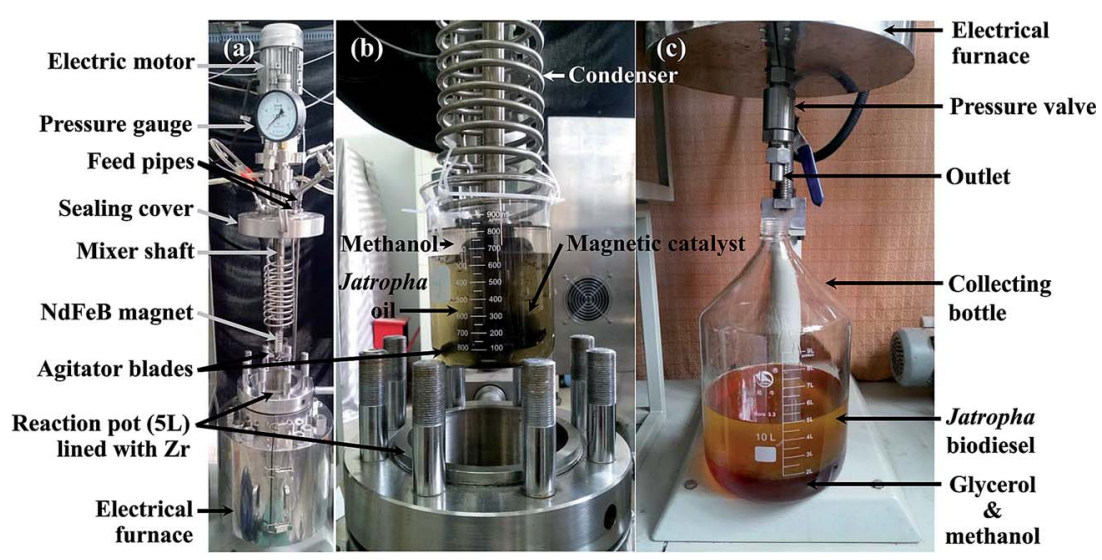

Fig. 2 Images of (a) the $5 \mathrm{~L}$ batch reactor used for the production of biodiesel, (b) the magnetic $\mathrm{JHC}-12-600-\mathrm{SO}_{3} \mathrm{H}\left(\mathrm{FFe} / \mathrm{Fe}{ }_{3} \mathrm{O}_{4} \mathrm{Catalyst}\right.$ attracted by the NdFeB magnet, which was attached to the mixer shaft, and (c) Jatropha biodiesel, glycerol and methanol pumped out of the reactor.

reactor was heated to $180{ }^{\circ} \mathrm{C}$ within $60 \mathrm{~min}$. After the reaction, the reactor was immediately cooled using circulating water for $0.5-$ $1 \mathrm{~h}$. The products were discharged slowly through the outlet valve (Fig. 2c), and the magnetic catalyst was collected on the mixer shaft attached to the NdFeB magnet for reuse.

After 3 cycles, the recycled catalyst was washed with an adequate amount of dehydrated ethanol 3-5 times and dried at $105{ }^{\circ} \mathrm{C}$ until a consistent weight was reached for calculation of the catalyst recovery rate.

Catalyst recovery $(\mathrm{wt} \%)=($ mass of recovered catalyst, $\mathrm{g}) /$

(mass of fresh catalyst, $\mathrm{g}$ ) $\times 100 \%$

\subsection{Biodiesel assays}

The AV (17.2 mg KOH per g) and saponification value (SV, $195.7 \mathrm{mg} \mathrm{KOH}$ per g) of the crude Jatropha oil samples were measured according to national standard protocols (GBT 55302005 and 5534-2008). The calculated average molecular weight of the crude oil was $942.9 \mathrm{~g} \mathrm{~mol}^{-1}$ according to the formula $[M=$ $(56.1 \times 1000 \times 3) /(\mathrm{SV}-\mathrm{AV})]^{30}$

The crude biodiesel that was produced was first clarified by being passed through a filter (pore size $0.22 \mu \mathrm{m}$, Merck Millipore). A Shimadzu gas chromatography (GC) system (GC-2014, Kyoto, Japan) equipped with a capillary column (Rtx-Wax, 30 $\mathrm{m} \times 0.25 \mathrm{~mm} \times 0.25 \mu \mathrm{m}$, Restek Corporation, Bellefonte, PA, USA) and a flame ionization detector (FID) was used for quantitative analysis of the yield of methyl esters in the product. Helium (99.999\%) was used as the carrier gas at a flow rate of 1 $\mathrm{mL} \min ^{-1}$. A $10 \mu \mathrm{L}$ sample was injected with a split ratio of $40: 1$. The temperatures of the column, injector and detector were maintained at 220,260 and $280{ }^{\circ} \mathrm{C}$, respectively.

The amount of methyl esters was calculated using $\mathrm{C}_{17: 0}$ as an internal standard. The yield of biodiesel was calculated by the equation reported in our previous work..$^{30}$

$$
\begin{aligned}
& \text { Biodiesel yield }(\mathrm{wt} \%)=\left\{\left[\left(A_{\mathrm{C} 16: 0} / f_{\mathrm{C} 16: 0}+A_{\mathrm{C} 16: 1} / f_{\mathrm{C} 16: 1}\right.\right.\right. \\
& \quad+A_{\mathrm{C} 18: 0} l f_{\mathrm{C} 18: 0}+A_{\mathrm{C} 18: 1} / f_{\mathrm{C} 18: 1}+A_{\mathrm{C} 18: 2} / f_{\mathrm{C} 18: 2}+A_{\mathrm{C} 18: 3} / f_{\mathrm{C} 18: 3} \\
& \left.\left.\quad+A_{\mathrm{Cothers}}\right) / A_{\mathrm{C} 17: 0} \times \times \text { weight of } \mathrm{C}_{17: 0}\right\} / \\
& \quad \text { (weight of crude biodiesel }) \times 100 \%
\end{aligned}
$$

where $A_{\mathrm{C} n}(n=16: 0,16: 1,18: 0,18: 1,18: 2$, and $18: 3)$ is the peak area for the six standard methyl esters $\left(\mathrm{C}_{16: 0}, \mathrm{C}_{16: 1}\right.$, $\mathrm{C}_{18: 0}, \mathrm{C}_{18: 1}, \mathrm{C}_{18: 2}$, and $\left.\mathrm{C}_{18: 3}\right), A_{\text {Cothers }}$ is the peak area for the other components except $A_{\mathrm{C} n}$, and $f_{\mathrm{C} n}(1.014,1.023,1.076,1.038$, 1.019 , and 0.926) is the relative response factor of $\mathrm{C}_{n}$ to that of $\mathrm{C}_{17: 0} \cdot{ }^{31}$

\section{Results and discussion}

\subsection{Synthesis of magnetic carbonaceous acids}

3.1.1. Reaction time for hydrothermal precipitation. The different reaction times used in the hydrothermal precipitation (between 4 and $20 \mathrm{~h}$ ) of the magnetic carbonaceous precursors (JHC- $T_{1}-600 @ F e / \mathrm{Fe}_{3} \mathrm{O}_{4}$ ) were optimized with respect to the TAC and $\mathrm{Ms}$ of the final acid catalyst. After sulfonation at $180^{\circ} \mathrm{C}$ for $12 \mathrm{~h}$, the TAC and Ms of the JHC- $T_{1}-600-\mathrm{SO}_{3} \mathrm{H} @ \mathrm{Fe} / \mathrm{Fe}_{3} \mathrm{O}_{4}$ catalyst increased sharply from $0.290 \mathrm{mmol} \mathrm{g}^{-1}$ and $10.3 \mathrm{~A} \mathrm{~m}^{2} \mathrm{~kg}^{-1}$ to $1.80 \mathrm{mmol} \mathrm{g}^{-1}$ and $26.3 \mathrm{~A} \mathrm{~m}^{2} \mathrm{~kg}^{-1}$, respectively, as the reaction time increased from 4 to $8 \mathrm{~h}$ (Fig. 3a). When the reaction time was further increased to $12 \mathrm{~h}$ and then to $20 \mathrm{~h}$, the Ms decreased from a maximum value of $40.3 \mathrm{~A} \mathrm{~m}^{2} \mathrm{~kg}^{-1}$ to $34.4 \mathrm{~A} \mathrm{~m}^{2}$ $\mathrm{kg}^{-1}$, but the TAC continuously increased from $2.69 \mathrm{mmol} \mathrm{g}^{-1}$ to $3.01 \mathrm{mmol} \mathrm{g}^{-1}$.

With an increase in the hydrothermal precipitation time, the increase in the loading capacity of JHC-4-600@Fe $/ \mathrm{Fe}_{3} \mathrm{O}_{4}$ for $-\mathrm{SO}_{3} \mathrm{H}$ groups was attributed to the growth in the carbonaceous surface areas of the magnetic cores via the continuous deposition of bulk carbon derived from the hydrolysates. SEM and TEM images (Fig. 4A-a and b) showed that a short precipitation time $(4 \mathrm{~h})$ led to a defective carbonaceous layer on the JHC-4$600 @ \mathrm{Fe} / \mathrm{Fe}_{3} \mathrm{O}_{4}$ precursor, which failed to protect the magnetic cores from corrosion by $\mathrm{H}_{2} \mathrm{SO}_{4}$ during sulfonation. EDX analysis (Fig. 4A-c) revealed that the carbon content was lower (6.60 wt\%) in comparison to that of $\mathrm{O}(22.6 \mathrm{wt} \%)$ or $\mathrm{Fe}(70.8 \mathrm{wt} \%)$ on the surface of the precursor. After hydrothermal precipitation for $20 \mathrm{~h}$, a complete carbonaceous coat was observed on JHC-20600- $\mathrm{SO}_{3} \mathrm{H} @ \mathrm{Fe} / \mathrm{Fe}_{3} \mathrm{O}_{4}$ (Fig. 4B-a and b). The $\mathrm{C}$ and $\mathrm{S}$ contents (wt\%) that were determined significantly increased to 33.1 and 21.4, respectively, whereas the $\mathrm{O}$ and Fe contents decreased to 18.6 and 26.9, respectively (Fig. 4B-c). However, the overloaded 

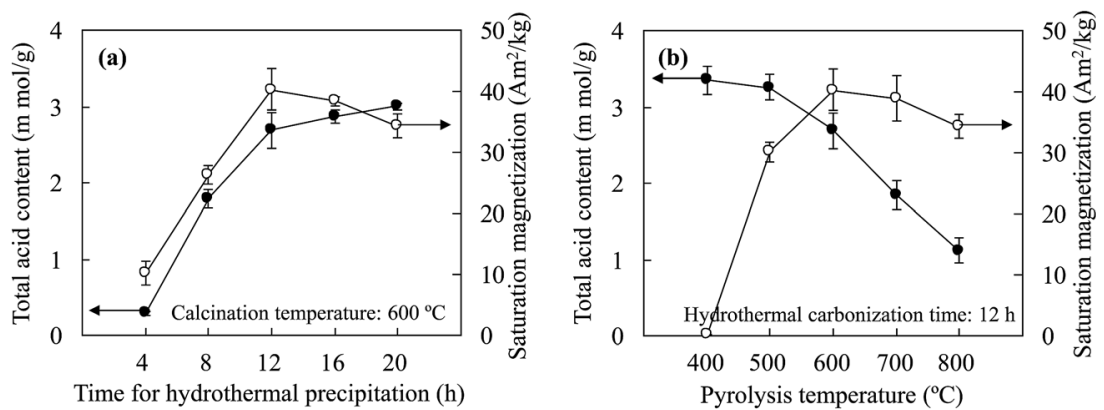

Fig. 3 Changes in the total acid content and saturation magnetization of the prepared solid acids versus (a) the hydrothermal precipitation time and (b) the carbonization temperature used in synthesis of the catalyst precursor.
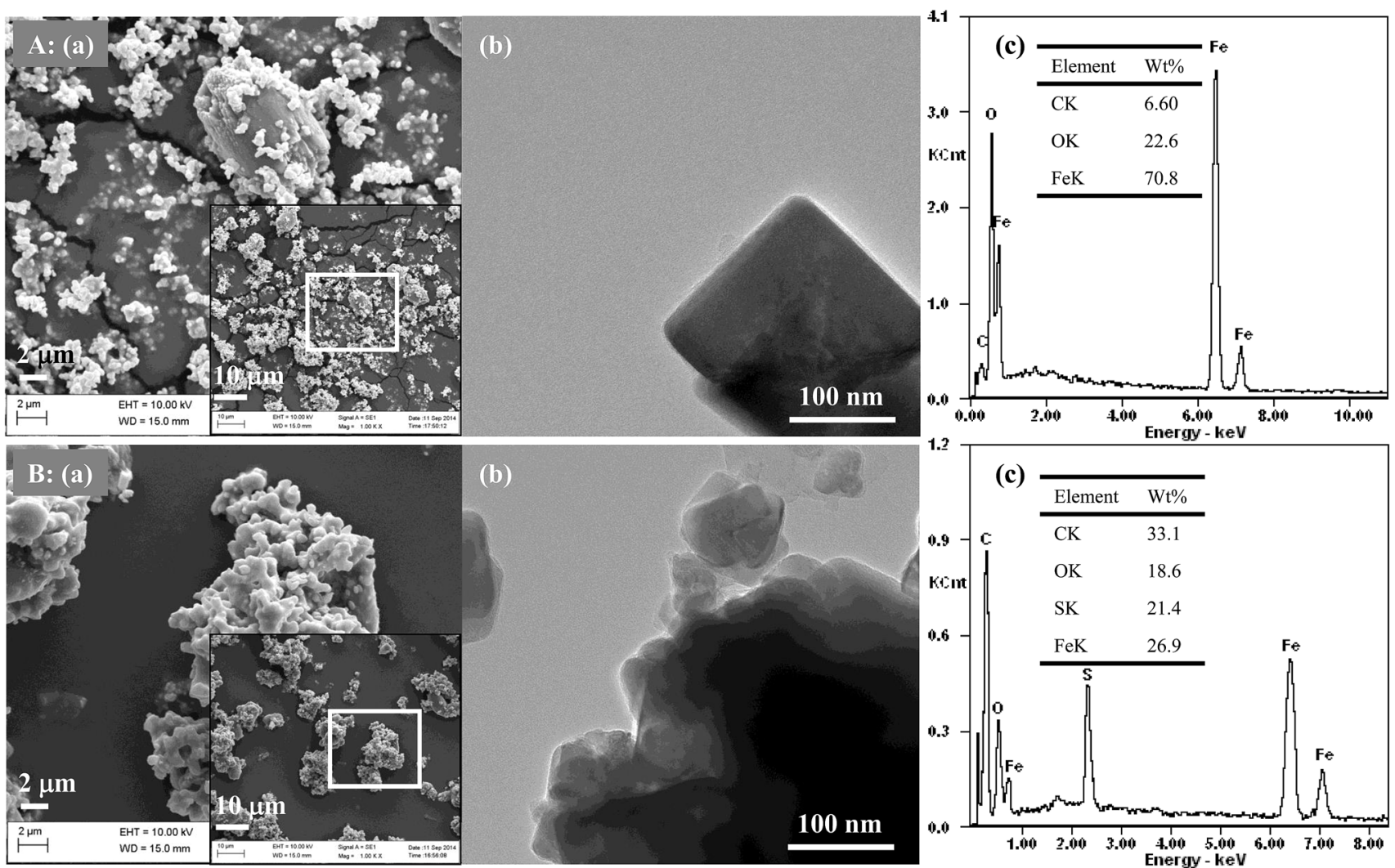

Fig. 4 Observations of the surface morphologies and microstructures of the catalyst and catalyst precursor: (a) SEM images, (b) TEM images and (c) EDX spectra of (A) the magnetic $\mathrm{JHC}-4-600$ a Fe/Fe $\mathrm{O}_{4}$ precursor and (B) the magnetic $\mathrm{JHC}-20-600-\mathrm{SO}_{3} \mathrm{H}\left(\mathrm{Fe} / \mathrm{Fe} \mathrm{O}_{4} \mathrm{catalyst}\right.$.

carbonaceous coat decreased the relative content of magnetic $\mathrm{Fe}_{3} \mathrm{O}_{4}$ in the catalyst and thus led to a slight reduction in the Ms. In this study, $12 \mathrm{~h}$ was selected as the best hydrothermal precipitation time for preparing the catalyst in the following experiments.

3.1.2. Carbonization temperature. Different temperatures were selected for the carbonization of the catalyst precursor JHC-12- $T_{2} @ \mathrm{Fe} / \mathrm{Fe}_{3} \mathrm{O}_{4}$ of between 400 and $800{ }^{\circ} \mathrm{C}$ (Fig. 3b). A temperature of $400{ }^{\circ} \mathrm{C}$ gave rise to an extremely weak Ms of the prepared catalyst JHC-12- $T_{2}-\mathrm{SO}_{3} \mathrm{H} @ \mathrm{Fe} / \mathrm{Fe}_{3} \mathrm{O}_{4}$ of $0.190 \mathrm{~A} \mathrm{~m}^{2} \mathrm{~kg}^{-1}$ after sulfonation for $12 \mathrm{~h}$ at $180{ }^{\circ} \mathrm{C}$. When the temperature was increased to $600{ }^{\circ} \mathrm{C}$, the Ms of the prepared catalyst reached a peak value of $40.3 \mathrm{~A} \mathrm{~m}^{2} \mathrm{~kg}^{-1}$.
The TAC was also affected by the carbonization temperature. In an analysis of the thermal stability of the JHC-12$200 @ \mathrm{Fe} / \mathrm{Fe}_{3} \mathrm{O}_{4}$ precursor, a weight loss (of about $6.06 \mathrm{wt} \%$ ) was observed at $203-400{ }^{\circ} \mathrm{C}$ (Fig. S1 $\dagger$ ), where the loss of $\mathrm{C}, \mathrm{H}$ and $\mathrm{O}$ elements (wt\%: C 41.8 vs. 36.3, H 4.93 vs. 3.97, O 19.6 vs. 17.0) was confirmed by elemental analysis (Table $\mathrm{S} 1 \dagger$ ). However, the JHC-12-400@Fe/ $/ \mathrm{Fe}_{3} \mathrm{O}_{4}$ and JHC-12-600@Fe/ $/ \mathrm{Fe}_{3} \mathrm{O}_{4}$ precursors, which had similar elemental contents (Table S1, $\dagger$ wt\%: C 36.3 vs. $35.1, \mathrm{H} 3.97$ vs. 3.88 , $\mathrm{O} 17.0$ vs. 16.2, Fe 40.7 vs. 42.9), possessed higher thermal stabilities up to a temperature of 400-601 ${ }^{\circ} \mathrm{C}$. The weight loss (about $0.90 \mathrm{wt} \%$, Fig. S $2 \dagger$ ) of the JHC-12-400@Fe $/ \mathrm{Fe}_{3} \mathrm{O}_{4}$ precursor indicated the slight release of volatile compounds from the sample. The significant weight 
loss (about $3.06 \mathrm{wt} \%$, Fig. S1 $\dagger$ ) between 601 and $800{ }^{\circ} \mathrm{C}$ could be due to the reaction $\mathrm{C}+\mathrm{Fe}_{3} \mathrm{O}_{4} \rightarrow \mathrm{Fe} / \mathrm{Fe}_{3} \mathrm{C}+\mathrm{CO}_{2} \uparrow$, with decreases in the $\mathrm{C}$ and $\mathrm{O}$ contents to $31.6 \mathrm{wt} \%$ and $13.4 \mathrm{wt} \%$, respectively. In addition, XRD analysis confirmed the formation of $\mathrm{Fe}$ and $\mathrm{Fe}_{3} \mathrm{C}$ in the sample (Fig. 5A-a). ${ }^{28}$

Lower temperatures ensured a moderate content of hydrogen and oxygen atoms, which could be bonded by $-\mathrm{SO}_{3} \mathrm{H}$ groups on the surface of the precursor. ${ }^{32}$ With an excessive carbonization temperature, the loss of active bonding sites for the formation of layers of aromatic carbon on the surface of the precursor would significantly impair the efficiency of sulfonation. ${ }^{33}$ With an increase in the carbonization temperature from 400 to $800{ }^{\circ} \mathrm{C}$, the TAC of the catalysts exhibited a dramatic decrease from $3.35 \mathrm{mmol} \mathrm{g}^{-1}$ to $1.12 \mathrm{mmol} \mathrm{g}^{-1}$. To achieve a balance between the Ms and TAC, $600{ }^{\circ} \mathrm{C}$ was selected as the optimized temperature for the carbonization of the precursor. Under these conditions, the TAC and Ms of the prepared JHC$12-600-\mathrm{SO}_{3} \mathrm{H} @ \mathrm{Fe} / \mathrm{Fe}_{3} \mathrm{O}_{4}$ were $2.69 \mathrm{mmol} \mathrm{g}{ }^{-1}$ and $40.3 \mathrm{~A} \mathrm{~m}^{2}$ $\mathrm{kg}^{-1}$, respectively.

\subsection{Characteristics of JHC-12-600@Fe/ $/ \mathrm{Fe}_{3} \mathrm{O}_{4}$ and JHC-12- $600-\mathrm{SO}_{3} \mathrm{H} @ \mathrm{Fe} / \mathrm{Fe}_{3} \mathrm{O}_{4}$}

3.2.1. XRD and VSM. The XRD pattern of JHC-12-600@Fe/ $\mathrm{Fe}_{3} \mathrm{O}_{4}$ displayed strong signals of a well-crystallized $\mathrm{Fe}$ structure (Fig. 5A-a), but the peak intensities for the crystal structures of $\mathrm{Fe}_{3} \mathrm{O}_{4}$ and $\mathrm{Fe}_{3} \mathrm{C}$ were low. This indicated the reduction of $\mathrm{Fe}_{3} \mathrm{O}_{4}$ to $\mathrm{Fe}$ and further to $\mathrm{Fe}_{3} \mathrm{C}$ at $600{ }^{\circ} \mathrm{C}$ via the reactions $\left[\mathrm{Fe}_{3} \mathrm{O}_{4}+\mathrm{C} \rightarrow \mathrm{Fe}+\mathrm{CO}_{2} / \mathrm{CO} \uparrow\right]$ and $[\mathrm{Fe}+\mathrm{C} \rightarrow$ $\left.\mathrm{Fe}_{3} \mathrm{C}\right] .^{34,35}$ The JHC-12-600- $\mathrm{SO}_{3} \mathrm{H} @ \mathrm{Fe} / \mathrm{Fe}_{3} \mathrm{O}_{4}$ catalyst displayed a distinct diffraction pattern (Fig. 5A-b). The appearance of $\mathrm{Fe}_{2} \mathrm{O}_{3}$ peaks revealed the occurrence of the reaction $[\mathrm{Fe}+$ $\left.\mathrm{H}_{2} \mathrm{SO}_{4} \rightarrow \mathrm{Fe}_{2} \mathrm{O}_{3}+\mathrm{H}_{2} \mathrm{O}+\mathrm{SO}_{2} \uparrow\right]$ during the sulfonation process. The $\mathrm{Fe}_{2} \mathrm{O}_{3}$ film could have protected the inner $\mathrm{Fe}$ core from further corrosion by $\mathrm{H}_{2} \mathrm{SO}_{4}$, which led to diminished diffraction peaks of Fe. Moreover, the JHC-12-600$\mathrm{SO}_{3} \mathrm{H} @ \mathrm{Fe} / \mathrm{Fe}_{3} \mathrm{O}_{4}$ catalyst also exhibited a strong diffraction peak (at $2 \theta=20-30^{\circ}$ ), which demonstrated the presence of aromatic carbon sheets, ${ }^{26}$ with a randomly oriented surface of amorphous carbons. ${ }^{36}$
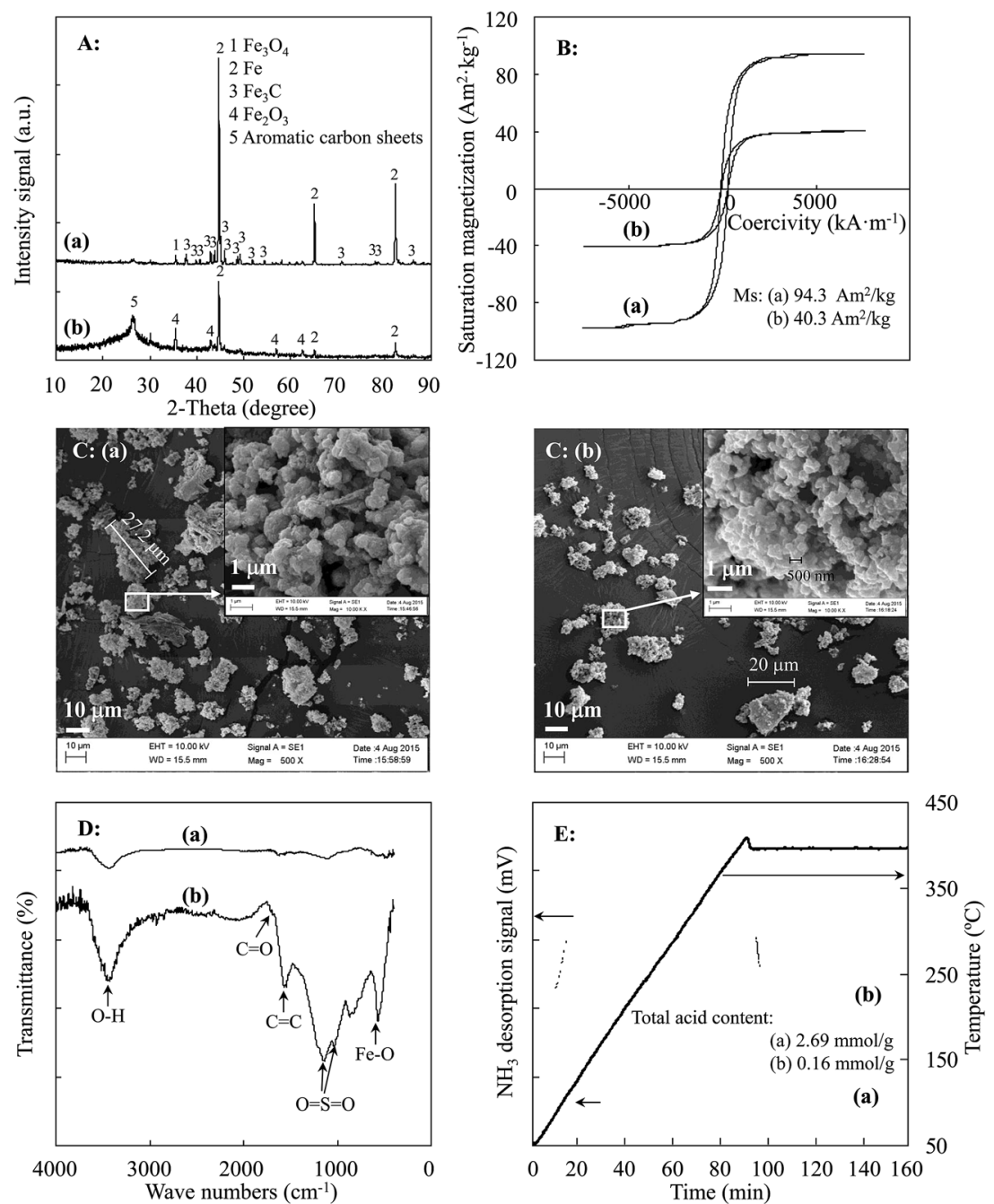

Fig. 5 Characterization of (a) magnetic JHC-12-600@ $\mathrm{Fe} / \mathrm{Fe}_{3} \mathrm{O}_{4}$ precursor and (b) magnetic JHC-12-600-SO ${ }_{3} \mathrm{H} @ \mathrm{Fe} / \mathrm{Fe}{ }_{3} \mathrm{O}_{4}$ catalyst: (A) XRD, (B) VSM, (C) SEM, (D) FT-IR, and (E) $\mathrm{NH}_{3}-\mathrm{TPD}$. 
As magnetic $\mathrm{Fe}$ and $\mathrm{Fe}_{3} \mathrm{C}$ have a higher magnetic saturation than $\mathrm{Fe}_{3} \mathrm{O}_{4},{ }^{37} \mathrm{JHC}-12-600 @ \mathrm{Fe} / \mathrm{Fe}_{3} \mathrm{O}_{4}$ had a higher magnetic saturation of $94.3 \mathrm{~A} \mathrm{~m}^{2} \mathrm{~kg}^{-1}$ than that of carbonaceous $\mathrm{Fe}_{3} \mathrm{O}_{4}$ owing to the remarkable conversion of $\mathrm{Fe}_{3} \mathrm{O}_{4}$ into $\mathrm{Fe}$ and $\mathrm{Fe}_{3} \mathrm{C}^{28}$ Owing to the loss of $\mathrm{Fe}_{3} \mathrm{O}_{4}$ and $\mathrm{Fe}_{3} \mathrm{C}$, which was caused by dissolution in the concentrated $\mathrm{H}_{2} \mathrm{SO}_{4}$ solution, the Ms of JHC12-600- $\mathrm{SO}_{3} \mathrm{H} @ \mathrm{Fe} / \mathrm{Fe}_{3} \mathrm{O}_{4}$ declined to $40.3 \mathrm{~A} \mathrm{~m}^{2} \mathrm{~kg}^{-1}$ (Fig. 5B). However, the $\mathrm{Ms}$ of $\mathrm{JHC}-12-600-\mathrm{SO}_{3} \mathrm{H} @ \mathrm{Fe} / \mathrm{Fe}_{3} \mathrm{O}_{4}$ was still stronger than that of the $\mathrm{AC}-600-\mathrm{SO}_{3} \mathrm{H} @ \mathrm{Fe} / \mathrm{C}$ catalyst, which was only $14.4 \mathrm{~A} \mathrm{~m}^{2} \mathrm{~kg}^{-1} .^{28}$

3.2.2. SEM and BET. SEM analysis (Fig. 5C-a) showed small-sized agglomerates of the JHC-12-600@Fe/ $/ \mathrm{Fe}_{3} \mathrm{O}_{4}$ precursor with smaller rough particles on their surface. This was distinct from the pattern in which AC-600@Fe/C agglomerated in the form of smooth spheres with a size of 50-100 $\mu \mathrm{m}$ in previous works. ${ }^{28}$ It was also observed that the JHC-12-600$\mathrm{SO}_{3} \mathrm{H} @ \mathrm{Fe} / \mathrm{Fe}_{3} \mathrm{O}_{4}$ catalyst contained agglomerated particles with a better size $(<30 \mu \mathrm{m})$ (Fig. $5 \mathrm{C}-\mathrm{b})$. The size of the particles was smaller than that of the agglomerated $\mathrm{AC}-600-\mathrm{SO}_{3} \mathrm{H} @ \mathrm{Fe} / \mathrm{C}$ catalyst $(50-100 \mu \mathrm{m})$. As metal oxides were exposed on the surface of the catalyst precursor without complete coverage by carbonaceous materials, JHC-12-600@Fe $/ \mathrm{Fe}_{3} \mathrm{O}_{4}$ could be corroded internally owing to penetration by $\mathrm{H}_{2} \mathrm{SO}_{4}$ during sulfonation. Therefore, the size of the JHC-12-600-SO $\mathrm{S}_{3} \mathrm{H} @ \mathrm{Fe} /$ $\mathrm{Fe}_{3} \mathrm{O}_{4}$ particles was slightly reduced $(<20 \mu \mathrm{m})$, with numerous spherical nanoparticles (size of $<500 \mathrm{~nm}$ ) attached to the surface (Fig. 5C-b). In addition to the change in the morphological pattern, the reduction in particle size and formation of microporous structures, as well as the removal of residual $\mathrm{Fe}_{3} \mathrm{C}$ particles from the surface of the precursor contributed to the increase in the surface area and pore volume of the catalyst. Nitrogen adsorption-desorption isotherms are shown in Fig. S2. $\dagger$ In comparison with JHC-12-600@Fe/ $/ \mathrm{Fe}_{3} \mathrm{O}_{4}$, the specific surface area and pore volume of JHC-12-600- $\mathrm{SO}_{3} \mathrm{H} @ \mathrm{Fe} / \mathrm{Fe}_{3} \mathrm{O}_{4}$ increased from $23.5 \mathrm{~m}^{2} \mathrm{~g}^{-1}$ and $0.048 \mathrm{~cm}^{3} \mathrm{~g}^{-1}$ to $46.7 \mathrm{~m}^{2} \mathrm{~g}^{-1}$ and $0.093 \mathrm{~cm}^{3} \mathrm{~g}^{-1}$, respectively. Furthermore, it was observed that the sulfonation process could reduce the average pore width from $24.6 \mathrm{~nm}$ in the precursor to $8.95 \mathrm{~nm}$ in the catalyst. This phenomenon could be explained by (i) the dissolution of $\mathrm{Fe}_{3} \mathrm{O}_{4}$ and $\mathrm{Fe}_{3} \mathrm{C}$ in the $\mathrm{JHC}-12-600 @ \mathrm{Fe} / \mathrm{Fe}_{3} \mathrm{O}_{4}$ precursor by concentrated $\mathrm{H}_{2} \mathrm{SO}_{4}$ (Fig. 5A-a) and (ii) occupation of the pore volume by newly formed active groups. ${ }^{28}$

3.2.3. FT-IR, elemental analysis and $\mathbf{N H}_{3}$-TPD. The FT-IR absorption spectra (Fig. 5D) exhibited stretching vibrations of $\mathrm{O}-\mathrm{H}$ and $\mathrm{C}=\mathrm{O}$ bonds at $3460 \mathrm{~cm}^{-1}$ and $1610 \mathrm{~cm}^{-1}$, respectively, which indicated the presence of $-\mathrm{OH}$ and $-\mathrm{COOH}$ groups in both JHC-12-600@Fe $/ \mathrm{Fe}_{3} \mathrm{O}_{4}$ and JHC-12-600- $\mathrm{SO}_{3} \mathrm{H} @ \mathrm{Fe} / \mathrm{Fe}_{3} \mathrm{O}_{4} \cdot{ }^{24}$ The formation of $\mathrm{Fe}_{2} \mathrm{O}_{3}$ in $\mathrm{JHC}-12-600-\mathrm{SO}_{3} \mathrm{H} @ \mathrm{Fe} / \mathrm{Fe}_{3} \mathrm{O}_{4}$ was indicated by the $\mathrm{Fe}-\mathrm{O}$ stretching vibration at $560 \mathrm{~cm}^{-1}$, which was further confirmed by the XRD analysis (Fig. 5A-b). Moreover, the $\mathrm{C}=\mathrm{C}$ stretching vibration at $1640 \mathrm{~cm}^{-1}$ and the $\mathrm{C}-\mathrm{O}-\mathrm{S}$ and $\mathrm{O}=\mathrm{S}=\mathrm{O}$ stretching vibrations at 1054-1060 and 1140-1180 $\mathrm{cm}^{-1}$ indicated the introduction of aromatic carbons and $-\mathrm{SO}_{3} \mathrm{H}$ groups, respectively, into the $\mathrm{JHC}-12-600-\mathrm{SO}_{3} \mathrm{H} @ \mathrm{Fe} /$ $\mathrm{Fe}_{3} \mathrm{O}_{4}$ catalyst (Fig. 5D-b). ${ }^{20,28}$

The content of sulfonic acid groups $\left(-\mathrm{SO}_{3} \mathrm{H}\right)$ in the JHC-12$600-\mathrm{SO}_{3} \mathrm{H} @ \mathrm{Fe} / \mathrm{Fe}_{3} \mathrm{O}_{4}$ catalyst was $1.13 \mathrm{mmol} \mathrm{g}{ }^{-1}$, as calculated by elemental analysis, which showed a remarkable increase in the $\mathrm{S}$ content after sulfonation (Table 2). With the active $-\mathrm{SO}_{3} \mathrm{H}$ groups, the TAC of the catalyst reached $2.69 \mathrm{mmol} \mathrm{g}^{-1}$, as determined by $\mathrm{NH}_{3}$-TPD (Fig. 5E-b). The sulfonation treatment led to an increase of $1680 \%$ in the total acidity of JHC-12$600 @ \mathrm{Fe} / \mathrm{Fe}_{3} \mathrm{O}_{4}$, in which the original $-\mathrm{OH}$ and $-\mathrm{COOH}^{28}$ groups only displayed an acidity of $0.16 \mathrm{mmol} \mathrm{g}^{-1}$. With its high acidity, JHC-12-600- $\mathrm{SO}_{3} \mathrm{H} @ \mathrm{Fe} / \mathrm{Fe}_{3} \mathrm{O}_{4}$ could be a favorable candidate as a catalyst for the production of biodiesel from Jatropha oil with a high AV.

\subsection{Production of Jatropha biodiesel with JHC-12-600- $\mathrm{SO}_{3} \mathrm{H} @ \mathrm{Fe} / \mathrm{Fe}_{3} \mathrm{O}_{4}$}

According to previously reported conditions for the production of biodiesel (catalyst loading of $10 \mathrm{wt} \%$, a molar ratio of methanol/ oil of $24 / 1$, a reaction temperature of $200{ }^{\circ} \mathrm{C}$ and a reaction time of $10 \mathrm{~h}),{ }^{28}$ optimization of the catalyst dosage (2.5-12.5 wt\% with respect to Jatropha oil), molar ratio of methanol to oil (6/1-30/1), reaction temperature $\left(180-220^{\circ} \mathrm{C}\right)$ and reaction time $(2.5-12.5 \mathrm{~h})$ for the production of Jatropha biodiesel was performed by singlefactor tests. Each run was duplicated and the average values of the results were reported (Fig. 6).

3.3.1. Methanol/oil molar ratio. Although a theoretical molar ratio of methanol/oil (MOR) of 3/1 has been proposed for the transesterification of triglycerides, higher MORs ranging from $6 / 1$ to $30 / 1$ have been widely used for reactions at high temperatures owing to extensive evaporation of methanol into the dead volume of the reactor. ${ }^{28}$ Fig. 6A-a shows that the biodiesel yield rapidly increased from $39.6 \%$ to $81.7 \%$ when the MOR increased from $6 / 1$ to $12 / 1$. The biodiesel yield reached a peak value of $94.2 \%$ at an MOR of $24 / 1$. A great increase in the ratio to $30 / 1$ led to a slight decline in the biodiesel yield to $92.7 \%$, as the excessive mass of methanol reduced the relative concentration of the catalyst in the reaction mixture. ${ }^{28}$

When the catalyst was reused, the biodiesel yield increased from $33.0 \%$ to a maximum value of $88.5 \%$ with an increase in the MOR from 6/1 to 18/1 (Fig. 6A-b). However, increases in the MOR to $24 / 1$ and further to 30/1 led to declines in the biodiesel yield to $85.5 \%$ and $82.1 \%$, respectively. A similar effect of an increase in MORs on changes in the biodiesel yield was revealed using either fresh or recycled catalysts. As the pore structures in magnetic JHC-12-600- $\mathrm{SO}_{3} \mathrm{H} @ \mathrm{Fe} / \mathrm{Fe}_{3} \mathrm{O}_{4}$ could be filled with methanol, the decline in the biodiesel yield was possibly due to a relatively low catalyst concentration that was caused by the higher MOR in the reaction system. ${ }^{28}$ Therefore, 18/1 was selected as the optimum MOR in the following experiments.

3.3.2. Catalyst loading. A catalyst loading of $2.5 \mathrm{wt} \%$ to 12.5 wt $\%$ with an MOR of $18 / 1$ was employed at $200{ }^{\circ} \mathrm{C}$ for $10 \mathrm{~h}$. The catalyst loading obviously affected the biodiesel yield when the fresh catalyst was used. With an increase in the catalyst loading from 2.5 to $7.5 \mathrm{wt} \%$, the biodiesel yield increased from $66.5 \%$ to 94.6\% (Fig. 6B-a). Further increases in the catalyst loading to 10 and $12.5 \mathrm{wt} \%$ led to a slight decrease in the biodiesel yield from $94.1 \%$ to $91.8 \%$ owing to poor distribution of the catalyst at high concentrations by magnetic stirring within a limited volume. ${ }^{28}$ 

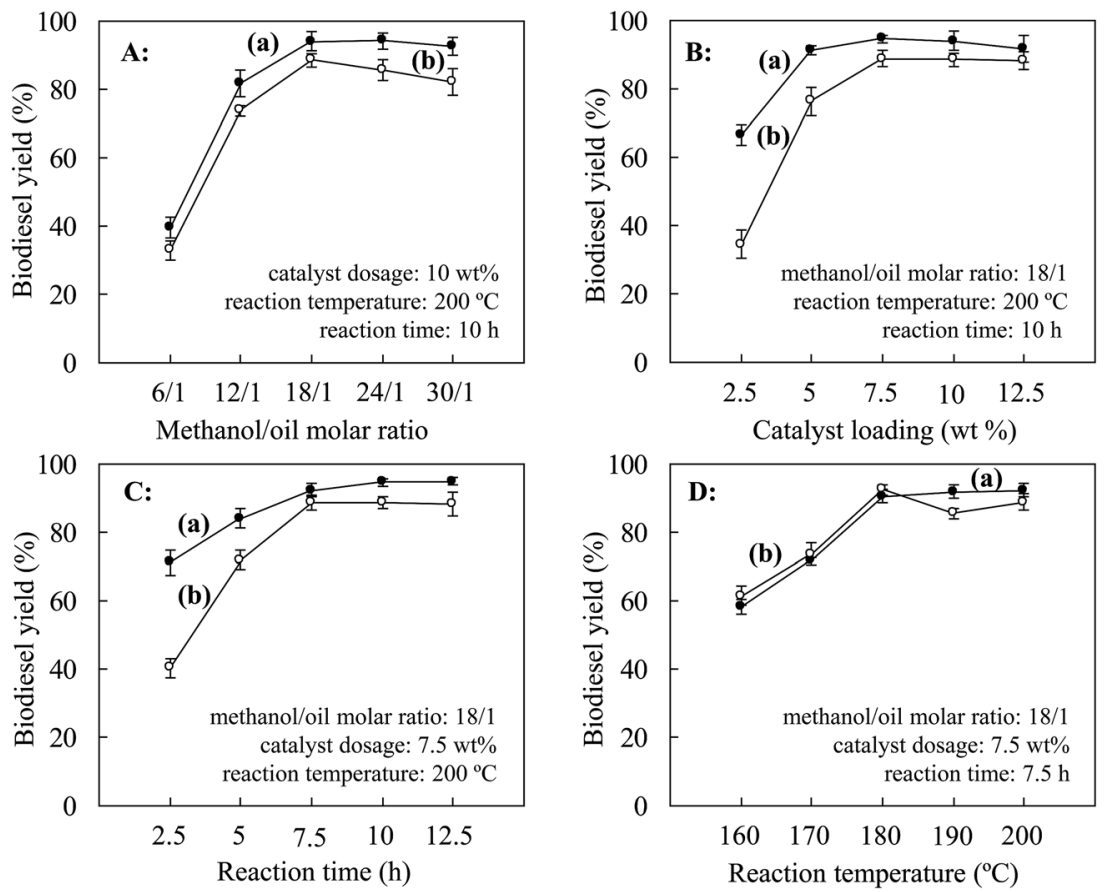

Fig. 6 Single-factor optimization of production of biodiesel from Jatropha oil with the magnetic $\mathrm{JHC}-12-600-\mathrm{SO}_{3} \mathrm{H}\left(\mathrm{Fe} / \mathrm{Fe}{ }_{3} \mathrm{O}{ }_{4} \mathrm{Catalyst}\right.$ used for (a) 1 and (b) 2 cycles: (A) methanol/oil molar ratio, (B) catalyst loading, (C) reaction time, and (D) reaction temperature.

The catalyst loading with the fresh catalyst and with the recycled catalyst displayed remarkable differences in their effect on the biodiesel yield. With a loading of $2.5 \mathrm{wt} \%$ of the fresh catalyst and when the catalyst had been used once, the biodiesel yield was $66.5 \%$ and $34.6 \%$, respectively (Fig. 6B-a and b). Increases in the catalyst loading to 5, 7.5, 10.0 and $12.5 \mathrm{wt} \%$ gradually narrowed the gap between the catalysts to $14.9 \%$, $5.8 \%, 5.6 \%$ and $3.5 \%$, respectively. To limit the cost by reducing the catalyst loading, $7.5 \mathrm{wt} \%$ was selected as the optimum level of catalyst loading.

3.3.3. Reaction time. Under conditions of an MOR of $18 / 1$, a catalyst loading of $7.5 \mathrm{wt} \%$ and a reaction temperature of $200{ }^{\circ} \mathrm{C}$, the biodiesel yield underwent a significant increase between reaction times of 2.5 and $7.5 \mathrm{~h}$ and reached a maximum value of $94.8 \%$ with the fresh catalyst after $12.5 \mathrm{~h}$ (Fig. 6C-a). Reuse of the catalyst caused a reduction in the biodiesel yield, owing to the loss of part of the active groups (Fig. 6C-b). ${ }^{28}$ However, the difference in biodiesel yield between the fresh and recycled catalysts decreased with an increase in the reaction time. A time of $7.5 \mathrm{~h}$ was selected as the optimum reaction time, with a reduction in efficiency of only $5.8 \%$ when the recycled catalyst was used.

3.3.4. Reaction temperature. Five reaction temperatures of between 160 and $200{ }^{\circ} \mathrm{C}$ were tested (Fig. 6D). When the fresh catalyst was used, a remarkable increase in the biodiesel yield from $58.3 \%$ to $90.6 \%$ occurred between 160 and $180{ }^{\circ} \mathrm{C}$. The biodiesel yield reached $92.0 \%$ at $190^{\circ} \mathrm{C}$ and increased slightly to $92.4 \%$ at $200{ }^{\circ} \mathrm{C}$ (Fig. 6D-a).

When the catalyst was reused, a similar trend of an increase in the biodiesel yield from $61.5 \%$ to $92.5 \%$ was achieved as the temperature was increased from 160 to $180{ }^{\circ} \mathrm{C}$ (Fig. 6D-b). However, with further increases in the temperature to $190{ }^{\circ} \mathrm{C}$ and $200{ }^{\circ} \mathrm{C}$, the biodiesel yield declined to $85.6 \%$ and $88.8 \%$, respectively, but was slightly promoted at the higher reaction temperature of $200^{\circ} \mathrm{C}$ via a change in the chemical equilibrium of the transesterification reactions. ${ }^{28}$ This indicated that firmly bonded active $-\mathrm{SO}_{3} \mathrm{H}$ groups on the fresh catalyst remained when the temperature was lower than $180{ }^{\circ} \mathrm{C}$, at which sulfonation and hydrothermal pretreatment were performed on the catalyst. ${ }^{28}$ Higher temperatures could cause a slight deactivation of the catalyst by releasing part of the active groups. Therefore, $180^{\circ} \mathrm{C}$ was selected as the optimum operating temperature of the catalyst.

\subsection{Performance of magnetic JHC-12-600-SO $\mathrm{S}_{3} \mathrm{H} @ \mathrm{Fe} / \mathrm{Fe}_{3} \mathrm{O}_{4}$ catalyst in scaled-up applications}

To evaluate the feasibility of using the magnetic JHC-12-600$\mathrm{SO}_{3} \mathrm{H} @ \mathrm{Fe} / \mathrm{Fe}_{3} \mathrm{O}_{4}$ catalyst for practical applications, the scaledup production of Jatropha biodiesel was performed with an MOR of $18 / 1$ and a catalyst loading of $7.5 \mathrm{wt} \%$ in a $5 \mathrm{~L}$ batch reactor (Fig. 2) at $180^{\circ} \mathrm{C}$ for $7.5 \mathrm{~h}$. Under optimal conditions, the JHC-12-600- $\mathrm{SO}_{3} \mathrm{H} @ \mathrm{Fe} / \mathrm{Fe}_{3} \mathrm{O}_{4}$ catalyst was reused for 5 cycles with an average recovery rate of $94.3 \pm 1.8 \mathrm{wt} \%$. The biodiesel yield was $96.5 \%, 97.4 \%, 96.7 \%, 95.6 \%$ and $93.2 \%$, respectively, whereas AV values of $0.25,0.19,0.27,0.36$ and $0.38 \mathrm{mg} \mathrm{KOH}$ per $\mathrm{g}$ were achieved after the first to fifth reaction cycles (Fig. 7). An average biodiesel yield of $95.9 \%$ and an AV of $0.29 \mathrm{mg} \mathrm{KOH}$ per $\mathrm{g}$ were achieved, which were slightly lower than the international standards for biodiesel products $(96.5 \%$ and $0.5 \mathrm{mg}$ KOH per g), respectively. ${ }^{38}$ The biodiesel yield reached $93.2 \%$ when the catalyst was reused for the fifth time. In comparison to $96.5 \%$, which was the biodiesel yield with the new catalyst, the decline was considered to be due to the leaching of $-\mathrm{SO}_{3} \mathrm{H}$ 


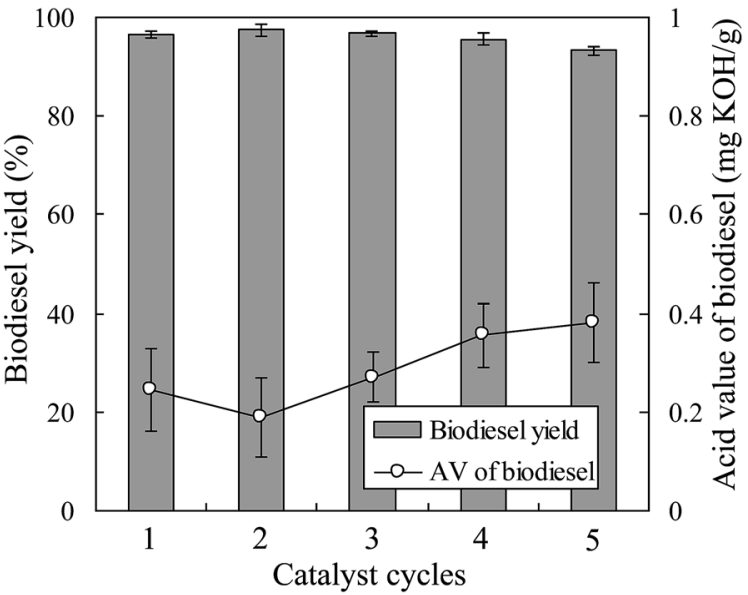

Fig. 7 Reuse of the $\mathrm{JHC}-12-600-\mathrm{SO}_{3} \mathrm{HaFe} / \mathrm{Fe}_{3} \mathrm{O}_{4}$ catalyst for the production of Jatropha biodiesel in a $5 \mathrm{~L}$ batch reactor (reaction conditions: $180^{\circ} \mathrm{C}$ for $7.5 \mathrm{~h}$ with a methanol/oil molar ratio of $18 / 1$ and a catalyst loading of $7.5 \mathrm{wt} \%$ ).

groups from the catalyst. On the basis of the reduction in the sulfur content from 3.62 to $2.37 \mathrm{wt} \%$ (Table 2), the calculated leaching rate of $-\mathrm{SO}_{3} \mathrm{H}$ groups was $34.5 \%$ on the assumption that all the sulfur atoms were associated with sulfonic acid groups. ${ }^{27,28}$

The scaled-up experiments resulted in much higher biodiesel yields than those achieved in the $50 \mathrm{~mL}$ batch reactor (96.5\% and $97.4 \%$ vs. $90.6 \%$ and $92.5 \%$ when the catalyst was used twice). This may have been caused by the difference in efficiency when mixing the catalysts with methanol and oil between agitator blades and magnetic stirrers (Fig. 2a vs. Fig. 1c). In comparison with the previous work, ${ }^{28}$ higher biodiesel yields were achieved $(90.6 \%$ and $92.5 \%$ vs. $90.5 \%$ and $91.8 \%$ for 2 reaction cycles) when the JHC-12-600- $-\mathrm{SO}_{3} \mathrm{H} @ \mathrm{Fe} /$ $\mathrm{Fe}_{3} \mathrm{O}_{4}$ catalyst was employed in the $50 \mathrm{~mL}$ batch reactor under much milder optimum conditions ( $v s$. an MOR of $24 / 1$ and a catalyst loading of $10 \mathrm{wt} \%$ at $200{ }^{\circ} \mathrm{C}$ for $10 \mathrm{~h}$ ). In addition, the Ms of the JHC-12-600- $\mathrm{SO}_{3} \mathrm{H} @ \mathrm{Fe} / \mathrm{Fe}_{3} \mathrm{O}_{4}$ catalyst was much higher than that of $\mathrm{AC}-600-\mathrm{SO}_{3} \mathrm{H} @ \mathrm{Fe} / \mathrm{C}\left(40.3 v s .14 .4 \mathrm{~A} \mathrm{~m}^{2} \mathrm{~kg}^{-1}\right)$, as was previously reported. A catalyst with a strong Ms would be more suitable for use in a scaled-up reactor, because its strong attraction to an $\mathrm{NdFeB}$ magnet will prevent it from being carried out by the discharged biodiesel product (Fig. 2).

With high values of TAC and Ms, JHC-12-600- $\mathrm{SO}_{3} \mathrm{H} @ \mathrm{Fe} /$ $\mathrm{Fe}_{3} \mathrm{O}_{4}$ displayed better performance in the direct production of biodiesel (Table 1). Moreover, this also indicates that JHC-12$600-\mathrm{SO}_{3} \mathrm{H} @ \mathrm{Fe} / \mathrm{Fe}_{3} \mathrm{O}_{4}$ potentially has high efficiency in the esterification of free fatty acids at low temperatures $\left(<100{ }^{\circ} \mathrm{C}\right) \cdot{ }^{22}$ Therefore, it could be combined with solid bases in the production of biodiesel from crude oils with a high AV via a twoprocess conversion method. ${ }^{39}$

\section{Conclusions}

Magnetic carbonaceous acids derived from hydrolysates of Jatropha hulls were successfully synthesized. The JHC-12-600-
$\mathrm{SO}_{3} \mathrm{H} @ \mathrm{Fe} / \mathrm{Fe}_{3} \mathrm{O}_{4}$ catalyst, which contained coating layers of aromatic carbon bonded to abundant active groups $(-\mathrm{OH}$, $-\mathrm{COOH}$ and $\left.-\mathrm{SO}_{3} \mathrm{H}\right)$, possessed a high TAC and $\mathrm{Ms}(2.69 \mathrm{mmol}$ $\mathrm{g}^{-1}$ and $40.3 \mathrm{~A} \mathrm{~m}^{2} \mathrm{~kg}^{-1}$ ). It displayed high activity and stability in the direct catalysis of the transesterification of Jatropha oil with a high $\mathrm{AV}$ (17.2 $\mathrm{mg} \mathrm{KOH}$ per g) for the production of biodiesel. In a $5 \mathrm{~L}$ batch reactor, JHC-12-600- $\mathrm{SO}_{3} \mathrm{H} @ \mathrm{Fe} / \mathrm{Fe}_{3} \mathrm{O}_{4}$ could be effectively recycled by a magnet for direct reuse. An average biodiesel yield of $95.9 \%$ was achieved after 5 reaction cycles with a catalyst recovery rate of $94.3 \%$. Owing to their stable performance and multiple potential applications, the synthesis of magnetic carbonaceous acids derived from the hydrolysates of Jatropha hulls enabled the green and economic utilization of energy plant waste in the co-production of biodiesel products.

\section{Acknowledgements}

The authors wish to acknowledge the financial support from the Youth Innovation Promotion Association CAS (No. 2017440) and Natural Science Foundation of China (No. 31400518).

\section{References}

1 M. Z. Jacobson, Energy Environ. Sci., 2009, 2, 148-173.

2 Z. Y. Hua, P. Q. Tan, X. Y. Yan and D. M. Lou, Energy, 2008, 33, 1654-1658.

3 L. Lin, C. S. Zhou, V. Saritporn, X. Q. Shen and M. D. Dong, Appl. Energy, 2011, 88, 1020-1031.

4 E. Lois, Fuel, 2007, 86, 1212-1213.

5 Q. Kwok, B. Acheson, R. Turcotte, A. Janès and G. Marlair, J. Therm. Anal. Calorim., 2013, 111, 507-515.

6 V. Mutreja, S. Singh, T. K. Minhas and A. Ali, RSC Adv., 2015, 5, 46890-46896.

7 S. B. Chavan, R. R. Kumbhar, D. Madhu, B. Singh and Y. C. Sharma, $R S C$ Adv., 2015, 5, 63596-63604.

8 S. Sharma, D. Medpelli, S. J. Chen and D. K. Seo, RSC Adv., 2015, 5, 65454-65461.

9 J. C. Juan, D. A. Kartika, T. Y. Wu and T. Y. Y. Hin, Bioresour. Technol., 2011, 102, 452-460.

10 H. C. Ong, A. S. Silitonga, H. H. Masjuki, T. M. I. Mahlia, W. T. Chong and M. H. Boosroh, Energy Convers. Manage., 2013, 73, 245-255.

11 M. Y. Koh and T. I. M. Ghazi, Renewable Sustainable Energy Rev., 2011, 15, 2240-2251.

12 S. Jain and M. P. Sharma, Energy, 2011, 36, 5409-5415.

13 F. Zhang, Z. Fang and Y. T. Wang, Fuel, 2015, 150, 370-377.

14 W. J. Li, Y. J. Gao, S. Y. Yao, D. Ma and N. Yan, Green Chem., 2015, 17, 4198-4205.

15 B. Norjannah, H. C. Ong, H. H. Masjuki, J. C. Juan and W. T. Chong, RSC Adv., 2016, 6, 60034-60055.

16 R. Hou, D. Zhang, X. Duan, X. Wang, S. Wang and Z. Sun, RSC Adv., 2016, 6, 81794-81801.

17 A. S. Badday, A. Z. Abdullah and K. T. Lee, Renewable Energy, 2013, 50, 427-432.

18 J. M. Rafi, A. Rajashekar, M. Srinivas, B. V. S. K. Rao, R. B. N. Prasad and N. Lingaiah, RSC Adv., 2015, 5, 4455044556. 
19 T. C. Su, Z. Fang, F. Zhang, J. Luo and X. K. Li, Sci. Rep., 2015, 5, 17538-17542.

20 E. L. S. Ngee, Y. J. Gao, X. Chen, T. M. Lee, Z. G. Hu, D. Zhao and N. Yan, Ind. Eng. Chem. Res., 2014, 53, 14225-14233.

21 H. C. Ong, A. S. Silitonga, H. H. Masjuki, T. M. I. Mahlia, W. T. Chong and M. H. Boosroh, Energy Convers. Manage., 2013, 73, 245-255.

22 F. L. Pua, Z. Fang, S. Zakaria, C. H. Chia and F. Guo, Biotechnol. Biofuels, 2011, 4, 56-64.

23 H. Cui, S. Q. Turn and M. A. Reese, Catal. Today, 2009, 139, 274-279.

24 L. Hu, X. Tang, Z. Wu, L. Lin, J. Xu, N. Xu and B. Dai, Chem. Eng. J., 2015, 263, 299-308.

25 Z. Liu, X. Fu, S. Tang, Y. Cheng, L. Zhu, L. Xing, J. Wang and L. Xue, Catal. Commun., 2014, 56, 1-4.

26 C. Zhang, H. Wang, F. Liu, L. Wang and H. He, Cellulose, 2013, 20, 127-134.

27 H. X. Guo, Y. F. Lian, L. L. Yan, X. H. Qi and R. L. Smith Jr, Green Chem., 2013, 15, 2167-2174.

28 F. Zhang, Z. Fang and Y. T. Wang, Appl. Energy, 2015, 155, 637-647.

29 K. Nakajima and M. Hara, J. Am. Ceram. Soc., 2007, 90, 37253734.
30 F. Zhang, X. H. Wu, M. Yao, Z. Fang and Y. T. Wang, Green Chem., 2016, 18, 3302-3314.

31 B. J. Xue, J. Luo, F. Zhang and Z. Fang, Energy, 2014, 68, 584591.

32 J. M. Anderson, R. L. Johnson, K. Schmidt-Rohr and B. H. Shanks, Carbon, 2014, 74, 333-345.

33 L. Wang, X. Dong, H. Jiang, G. Li and M. Zhang, Bioresour. Technol., 2014, 158, 392-395.

34 M. C. Pereira, F. S. Coelho, C. C. Nascentes, J. D. Fabris, M. H. Araújo, K. Sapag, L. C. A. Oliveira and R. M. Lago, Chemosphere, 2010, 81, 7-12.

35 Y. Fei and E. Brosh, Earth Planet. Sci. Lett., 2014, 408, 155162.

36 F. A. Dawodu, O. Ayodele, J. Xin, S. Zhang and D. Yan, Appl. Energy, 2014, 114, 819-826.

37 R. López de Arroyabe Loyo, S. I. Nikitenko, A. C. Scheinost and M. Simonoff, Environ. Sci. Technol., 2008, 42, 2451-2456.

38 M. Oguma, Y. J. Lee and S. Goto, Int. J. Automot. Tech., 2012, 13, 33-41.

39 P. M. Guo, F. H. Huang, M. M. Zheng, W. L. Li and Q. D. Huang, J. Am. Oil Chem. Soc., 2012, 89, 925-933. 